\title{
THE Cl-FLOW PROJECT A System for Total Water Level Prediction from the Summit to the Sea
}

\author{
by Suzanne Van Cooten, Kevin E. Kelleher, Kenneth Howard, Jian Zhang, Jonathan J. Gourley, \\ John S. Kain, Kodi Nemunaitis-Monroe, Zac Flamig, Heather Moser, Ami Arthur, Carrie Langston, \\ Randall Kolar, Yang Hong, Kendra Dresback, Evan Tromble, Humberto Vergara, Richard A luettich Jr., \\ Brian Blanton, Howard Lander, Ken Galluppi, Jessica Proud losego, Cheryl Ann Blain, Jack Thigpen, \\ Katie Mosher, Darin Figurskey, Michael Moneypenny, Jonathan Blaes, Jeff Orrock, Rich Bandy, \\ Carin Goodall, John G. W. Kelley, Jason Greenlaw, Micah Wengren, Dave Eslinger, Jeff Payne, \\ Geno Olmi, John Feldi, John Schmidt, Todd Hamill, Robert Bacon, Robert Stickney, and Lundie Spence
}

\section{A coupled modeling system, now in prototype stage, produces total water level simulations} for flooding in coastal watersheds.

K ildow et al. (2009) reported that coastal states support $81 \%$ of the U.S. population and generate 83 percent [ $\$ 11.4$ trillion (U.S. dollars) in 2007] of U.S. gross domestic product. Population trends show that a majority of coastal communities have transitioned from a seasonal, predominantly weekend, tourist-based economy to a year-round, permanently based, business economy where industry expands along shorelines and the workforce commutes from inland locations. As a result of this transition, costs associated with damage to the civil infrastructure and disruptions to local and regional economies due to coastal flooding events are escalating, pushing requirements for a new generation of flood prediction technologies and hydrologic decision support tools.

The CI-FLOW (see the appendix for acronym expansions) project is a multiorganizational, interdisciplinary research and development effort focused on improving NOAA's monitoring and prediction of total water level within tidally influenced watersheds. CI-FLOW leverages key strengths and capabilities of NOAA and its partners, including expertise in weather and hydrology, educational programming, and public outreach activities (Pietrafesa et al.
2006). Currently, CI-FLOW produces total water level simulations using a coupled modeling system that connects a distributed hydrologic model, forced with high-resolution QPE/QPF, to a hydrodynamic model, forced with river discharge, tidal elevations, and atmospheric and wave BCs. Organizations in this demonstration project, located in the Tar-Pamlico and Neuse River basins of North Carolina, include the following: NOAA's NSSL, NOAA's NSG College Program, OU, UNC-CH, and the Sea Grant programs of North Carolina, South Carolina, and Texas. This collaborative research activity emerged in response to a challenge by the director of NOAA's OAR to form a strategic and sustainable relationship between NSSL and Sea Grant to improve NOAA's services to coastal residents. The first meeting, held in February 2000, with the memory of Hurricanes Dennis and Floyd still fresh, focused on incorporating NSSL expertise in advanced precipitation estimation and severe storm forecasting into Sea Grant research and outreach activities. Today, CI-FLOW facilitates the evaluation and demonstration of capabilities provided by new remote sensing technologies, including dualpolarized radar and multisensor data assimilation, 
in coastal watersheds at higher spatial and temporal resolutions than previously possible to improve the monitoring and prediction of floods.

SOCIAL AND ECONOMIC HYDROLOGIC RISK FACTORS IN THE COASTAL ZONE.

Population and economic trends (Bin and Kruse 2006) in coastal counties have tremendous implications for how these areas respond to and recover from natural and man-made hazards, particularly those of a hydrologic/hydrodynamic nature (Willigen et al. 2005). Floods affect the entire spectrum of regional activities, from the morning commute to agribusiness to community decision making. As businesses expand into areas prone to storm surge, more drivers are vulnerable to floods as they navigate vehicles across low-lying coastal

\begin{tabular}{|c|c|c|c|c|c|c|c|c|c|}
\hline County & 1970 & 1980 & 1990 & 2000 & 2004 & $\begin{array}{l}\text { Population } \\
\text { change (\%) } \\
1970-2000\end{array}$ & $\begin{array}{c}\text { Population } \\
\text { density } \\
(2000)\end{array}$ & $\begin{array}{c}2000 \\
\text { total } \\
\text { housing } \\
\text { units }\end{array}$ & $\begin{array}{c}2000 \\
\text { seasonal } \\
\text { housing } \\
\text { units }\end{array}$ \\
\hline Beaufort & 35,980 & 40,355 & 42,283 & 44,958 & 45,794 & 25 & 54 & 22,139 & 1,890 \\
\hline Hyde & 5,571 & 5,873 & 5,411 & 5,826 & 5,521 & 5 & 10 & 3,302 & 666 \\
\hline Dare & 6,995 & 13,377 & 22,746 & 29,967 & 33,518 & 328 & 78 & 26,671 & 13,355 \\
\hline Pamlico & 9,467 & 10,398 & 11,372 & 12,934 & 12,814 & 37 & 38 & 6,781 & 903 \\
\hline Craven & 62,554 & 71,043 & 81,613 & 91,436 & 91,599 & 46 & 129 & 38,150 & 433 \\
\hline Carteret & 31,603 & 41,092 & 52,556 & 59,383 & 62,034 & 88 & 114 & 40,947 & 13,333 \\
\hline Lenoir & 55,204 & 59,819 & 57,274 & 59,648 & 58,424 & 8 & 149 & 27,184 & 82 \\
\hline Jones & 9,779 & 9,705 & 9,414 & 10,381 & 10,404 & 6 & 22 & 4,679 & 52 \\
\hline Pitt & 73,900 & 90,146 & 107,924 & 133,798 & 140,587 & 81 & 205 & 58,408 & 244 \\
\hline Martin & 24,730 & 25,948 & 25,078 & 25,593 & 24,796 & 3 & 56 & 10,930 & 89 \\
\hline Wayne & 85,408 & 97,054 & 104,666 & 113,329 & 114,245 & 33 & 205 & 47,313 & 175 \\
\hline Wilson & 57,486 & 63,132 & 66,061 & 73,814 & 76,091 & 28 & 199 & 30,729 & 110 \\
\hline Edgecombe & 52,341 & 55,988 & 56,558 & 55,606 & 54,713 & 6 & 110 & 24,002 & 131 \\
\hline Halifax & 53,884 & 55,286 & 55,516 & 57,370 & 56,034 & 6 & 79 & 25,309 & 712 \\
\hline Greene & 14,967 & 16,117 & 15,384 & 18,974 & 20,093 & 27 & 28 & 7,368 & 40 \\
\hline
\end{tabular}

Affiliations: Van Cooten, Kelleher, Howard, Zhang, Gourley, AND KaIN-NOAA/NSSL, Norman, Oklahoma; NemunaItIS-Monroe, FLAMIG, Moser, ArTHUR, AND LANGSTON-Cooperative Institute for Mesoscale Meteorological Studies, University of Oklahoma, and NOAA/NSSL, Norman, Oklahoma; KolAR, Hong, DresbaCK, TROMBLE, AND VERGARA-School of Civil Engineering and Environmental Science, University of Oklahoma, Norman, Oklahoma; LUETTICH - Institute of Marine Sciences, University of North Carolina at Chapel Hill, Morehead City, North Carolina; BLANTON, LANDER, GalluPPI, AND LOSEGO-RENCI, University of North Carolina at Chapel Hill, Chapel Hill, North Carolina; BLAINOceanography Division, Naval Research Laboratory, Stennis Space Center, Mississippi; Thigpen and Mosher-North Carolina Sea Grant, Raleigh, North Carolina; FIGURSkey, Moneypenny, Blaes, AND ORROCK-NOAA/NWS Forecast Office, Raleigh, North Carolina; BANDY AND GOODALL-NOAA/NWS Forecast Office, Newport, North Carolina; Kelley, GreenLaW, ANd Wengren-
NOAA/NOS/Coast Survey Development Laboratory, Silver Spring, Maryland; EsLINGer, PAYNe, AND OLMI-NOAA/CSC, Charleston, South Carolina; FELDT, SCHMIDT, AND HAMILL-NOAA/ NWS Southeast River Forecast Center, Peachtree City, Georgia; BACON-South Carolina Sea Grant, Charleston, South Carolina; StiCKNeY - Texas Sea Grant, College Station, Texas; SPENCECenters for Ocean Sciences Education Excellence-Southeast, Charleston, South Carolina

CORRESPONDING AUTHOR: Suzanne Van Cooten, NSSL, I20 David L. Boren Blvd., Norman, OK 73072

E-mail: suzanne.van.cooten@noaa.gov

The abstract for this article can be found in this issue, following the table of contents.

DOI:10.|175/201|BAMS3150.|

In final form 3I May 2011

(O)20II American Meteorological Society 
plains. Tourist areas experience increased urban development, which brings additional pollutants to beaches and estuaries from increased stormwater runoff.

Human factors are not only increasing the risk to life and property from flooding due to development practices, but they have also resulted in evacuation plans becoming obsolete as population densities in near-coastal counties rapidly increase (Dow and Cutter 2002; Urbina and Wolshon 2003). This trend is evident in the population statistics for eastern North Carolina (Table 1; North Carolina Office of State Budget and Management 2011). Cities and regions that in the past would have had the infrastructure and personnel to absorb the influx of coastal evacuees must now prioritize shelter options and increase emergency response services to serve their year-round residents. Half of our nation's population lives in the coastal zone, which supports more than $80 \%$ of the U.S. economy (Kildow et al. 2009). Accurate and timely water quantity information for coastal watersheds, inclusive of CDAs, ${ }^{1}$ provides tremendous economic and societal benefit.

PROJECT MOTIVATION. In the current state of NWS operations, the Tar-Pamlico River basin has one routine hydrologic forecast point and four flood-only forecast points (Fig. 1). The Neuse River has three routine hydrologic forecast points and two flood-only forecast

\footnotetext{
${ }^{1}$ NOAA (2010) defines a CDA as "that component of an entire watershed that meets the following three criteria: 1) it is not part of any estuary drainage area; 2) it drains directly into an ocean, an estuary, or the Great Lakes; and 3) it is composed only of the downstream-most HUC in which the head-of-tide is found." For the Atlantic seaboard region, extending from Maine to the east coast of Florida, and the Gulf of Mexico region, extending from the west coast of Florida to Texas, 142 CDAs are defined by the CAF. This manuscript's electronic supplement (http://dx.doi .org/10.1175/20IIBAMS3I50.2) provides the names of the CDAs and any NWS forecast points that may be associated with the CDA.
}

points (Fig. 1). The NWS routine forecast points are all upstream of the Tar-Pamlico and Neuse River CDAs. Many areas within the basins, including the coastal plain, do not receive any river stage forecasts from the NWS. The only water information available on a routine basis, and during most flooding events, for a majority of residents located in the headwaters and coastal plain of the two basins, is the discharge reading collected by the respective USGS gauge.

The scarcity of flood information is typical of the 142 CDAs along the U.S. Atlantic and Gulf of Mexico coastline. In the current state of NWS river forecast operations, more than $95 \%$ of Atlantic and Gulf of Mexico CDAs do not receive routine river forecasts of water level or streamflow. Even with consideration of flood-only forecast points, more than $90 \%$ of these CDAs do not receive any hydrologic information regarding water level and timing of flood crest from the NWS.

The sparse number of routine water level forecasts provided by the current NWS operational strategy offers tremendous opportunity for service enhancement. The SERFC is one of 13 NWS RFCs that issue river stage forecasts based on NWS operational

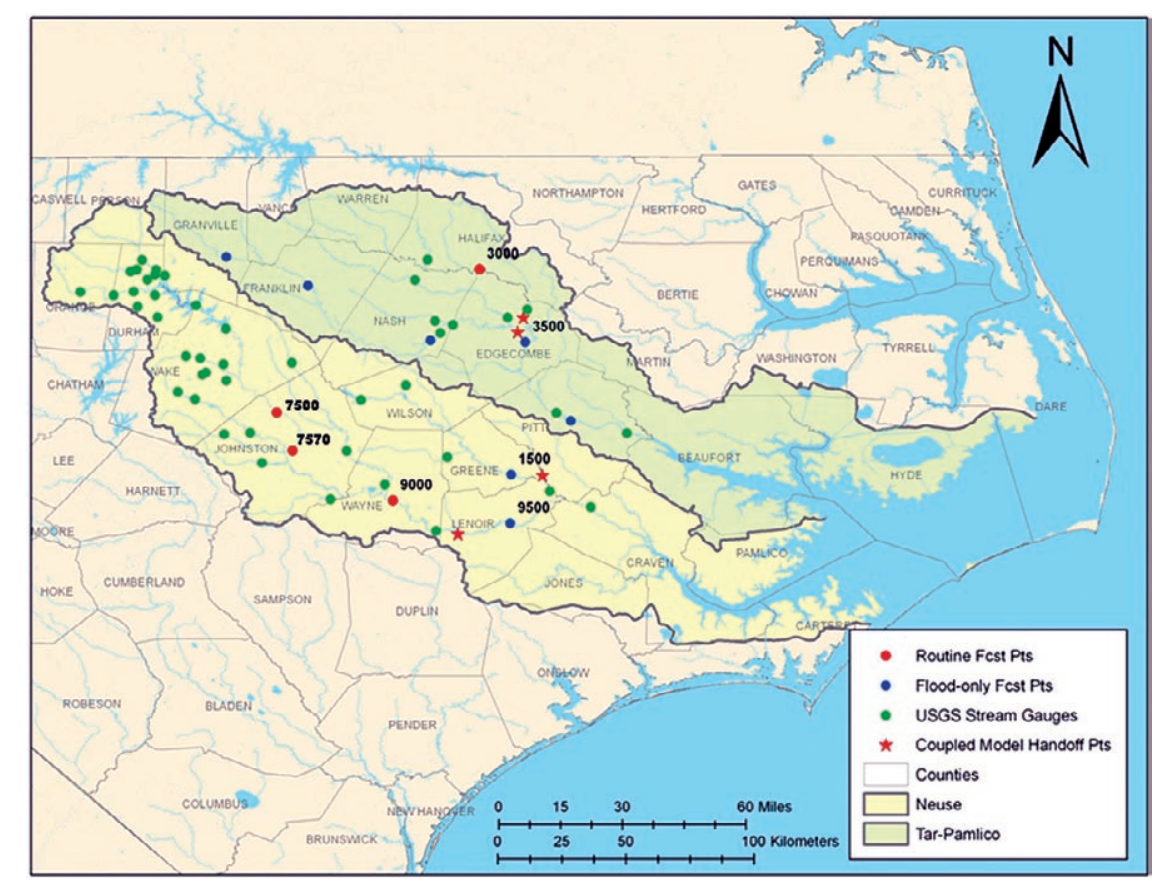

FIG. I. Eastern North Carolina with counties in the vicinity of the Tar-Pamlico River (green) and Neuse River (yellow) basins. Red circles are SERFC routine 5-day forecast points. Blue circles are SERFC flood-only forecast points. All circles, including the blue and the red, are USGS gauge locations. The red stars indicate the four handoff points between the CI-FLOW hydrologic model and the ocean hydrodynamic model, whose domain has been extended upland to incorporate the mainstem of the Tar-Pamlico and Neuse and two tributaries. 
methods (Stallings and Wenzel 1995; Larson et al. 1995; Fread et al. 1995). NWS RFCs tailor their forecasting methods to local watershed characteristics and the needs of the NWS Forecast Offices within their area of responsibility (Glaudemans et al. 2002; McEnery et al. 2005). One factor that contributes to the lack of forecast locations is the computational and workforce requirements needed to implement hydrologic models upland of the CDA. An even greater effort is required to implement the hydrodynamic models that simulate two-directional flow, which occurs with normal tidal movement and backwater effects due to storm surge.

The absence of accurate, high temporal and spatial resolution routine water level information within a coastal watershed, where population centers are growing and economies are expanding, is the fundamental motivation for CI-FLOW. NWS routine and flood-only forecast points are collocated with only a few of the USGS gauges monitoring the Tar-Pamlico and Neuse River basins (Fig. 1). Other datasets, such as high water marks, inundation maps, and NOAA tidal gauges/ buoys, provide additional verification information. Implementation of the CI-FLOW modeling system that couples atmospheric, hydrologic, and hydrodynamic models to produce total water level simulations for a 5-day forecast period for each of the USGS gauge locations and other observing

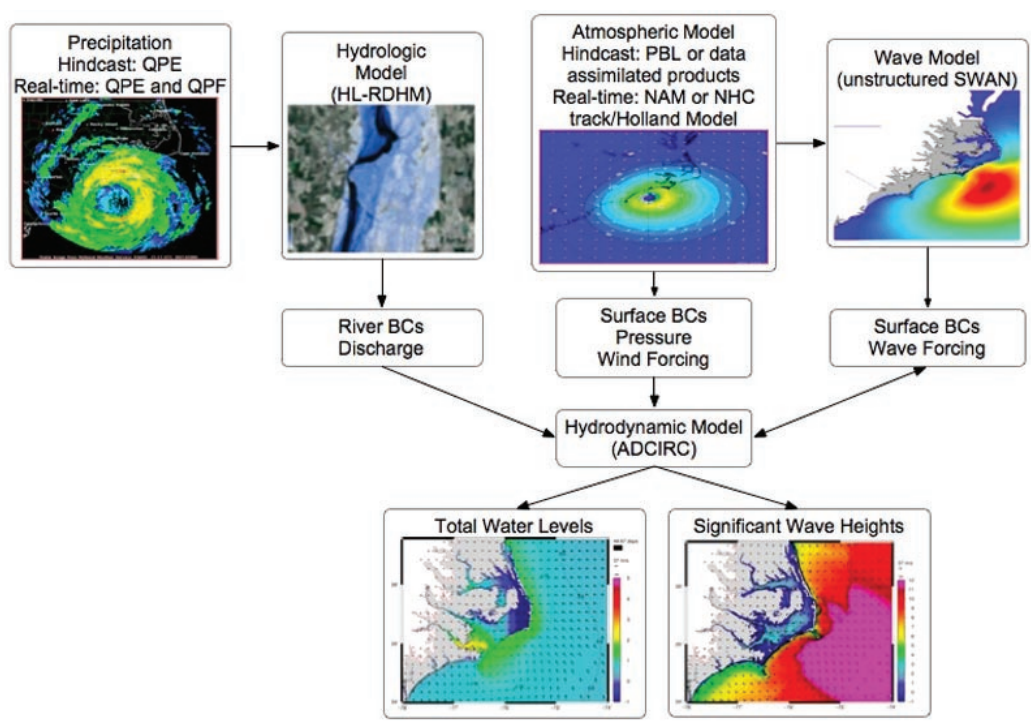

FIG. 2. Schematic illustrating the structure of the hindcast and real-time CI-FLOW system. For the hindcast system, only QPE is used for precipitation, and PBL or data-assimilated products are used for atmospheric model fields. In the real-time system, QPE and QPF fields are used for precipitation, and NAM or NHC guidance is used with the Holland model to generate atmospheric model fields (i.e., wind and pressure). sites results in a significant increase in the amount of routine hydrologic information available in the basins. Most importantly, the modeling system is technically capable of producing simulations for any given location, thus enabling the system to provide routine water quantity information from the headwaters of the Tar-Pamlico and Neuse Rivers to the Pamlico Sound, from the summit to the sea.

MODELING SYSTEM. The long-term goal of CIFLOW is to develop a system that couples multiple atmospheric, hydrologic, and hydrodynamic models that produce ensemble forecasts of total water level. Currently, the modeling system consists of the RUC model (Benjamin et al. 2004) for automated precipitation classifications for QPE, the NWS HL-RDHM (Koren et al. 2004; Smith et al. 2004; Reed et al. 2004; Moreda et al. 2006) for river discharge simulations, and the two-dimensional ADCIRC hydrodynamic model (www.adcirc.org; Luettich et al. 1992; Westerink et al. 1994), which has recently been dynamically coupled with an unstructured grid version of SWAN (Zijlema 2010; Dietrich et al. 2010a,b) to create ADCIRC+SWAN. Figure 2 shows a schematic of the system for hindcast and real-time operations, with details provided in later sections of this manuscript.

Hydrologic modeling system. Currently, CI-FLOW uses the HL-RDHM, developed by the NWS, to produce simulations of discharge for points along the mainstem and major tributaries of the Tar-Pamlico and Neuse Rivers. Using a distributed model, the HL-RDHM provides capability to produce river discharge simulations at any location in a river system, rather than just locations along the main channel and at the outlet of a subbasin. The HL-RDHM can ingest high spatial and temporal resolution QPE data, providing finer detail of storm-scale precipitation fields. The structure of the modeling system is based on the HRAP rectangular grid (Greene and Hudlow 1983; Reed and Maidment 1999) with the nominal gridcell resolution of $4 \mathrm{~km} \times 4 \mathrm{~km}$.

One challenge in implementing the HL-RDHM in the Tar-Pamlico and Neuse River 
basins was to ensure the HL-RDHM would initialize the soil moisture conditions using long-term precipitation datasets so that moisture fluxes are properly modeled. For a first estimate, subsurface moisture values were assigned based on assessments of the condition of the soil states given in the STATSGO database (Soil Survey Staff 1994, 1996; USDA 1994). These values were then modified based on Sacramento Soil Moisture Accounting model (Burnash 1995; Smith et al. 2003) parameters recommended for the eastern North Carolina region, which account for spatial resolution issues inherent in the STATSGO database (Miller and White 1998; Hernandez et al. 2000).

Once these states were provided to the model, researchers used the NCEP hourly stage IV (Fulton et al. 1998; Lin and Mitchell 2005) dataset for the long-term run of the HL-RDHM. Using a continuous hourly precipitation record from 2002 to 2008 , researchers examined how the HL-RDHM performed for multiple precipitation events in different seasons and in different weather patterns. Once this assessment was completed, the HL-RDHM parameters were adjusted to optimize the CI-FLOW streamflow discharge simulations.

Hourly discharge values for two USGS gauge locations, Tarboro (TARN7) and Kinston (KINN7), numbered 3500 and 9500, respectively, in Fig. 1, were produced by the HL-RDHM, forced with QPE data from the NWS MPE system using the optimized HL-RDHM parameters, for a period from January 2003 through December 2006. Results, not presented herein, showed the optimized HL-RDHM verified well with USGS observations using QPE data from the NWS MPE system.

To ensure the HL-RDHM's ability to produce hourly streamflow discharge simulations during a real-time event, a final test was completed using the elements and data flow of the real-time CI-FLOW system (Fig. 2). In this final test, QPE data from NSSL's Q2 system (Vasiloff and Kaney 2007; Vasiloff et al. 2007; Zhang et al. 2011) were used as forcing for the optimized HL-RDHM. The HL-RDHM successfully produced discharge simulations for TARN7 and KINN7, demonstrating the HL-RDHM's ability to produce hourly streamflow discharge simulations during a real-time event.
Hydrodynamic modeling system. In 2007, researchers at OU CEES, UNC-CH IMS, and the state of North Carolina's RENCI approached NSSL to collaborate on a NOAA IOOS storm surge proposal. This activity supported bringing the ADCIRC hydrodynamic model (Luettich et al. 1992; Westerink et al. 1994) and the dynamically coupled unstructured grid version of the coastal wave model SWAN (Zijlema 2010; Dietrich et al. 2010a,b) into the CI-FLOW system. ADCIRC+SWAN provides total water level forecasting capability for coastal areas by accounting for river discharges, waves, tides, and surge. Methods previously used to simulate near-shore waves in ADCIRC utilized either the SWAN model (Ris et al. 1999; Booij et al. 1999, 2004) or the Steady-State Spectral Wave model (McKee Smith et al. 2001) in a loosely coupled fashion, while deep-water waves were accounted for by either using the Wave Amplitude Model (WAMDI Group 1988; Gunther 2005) or WaveWatch III (Tolman 2009) models. These latter models were used extensively in several hurricane studies (Funakoshi et al. 2008; Dietrich et al. 2010a,b; Bunya et al. 2010). One problem encountered when using this loosely coupled method of integrating waves was the mapping between the structured grids of the aforementioned wave models to the unstructured grid of ADCIRC, which limited the number of times information could be shared between models during a simulation. To address this problem, Zijlema (2010) and Dietrich et al. (2010a,b) dynamically coupled an unstructured grid version of SWAN to ADCIRC. These new enhancements allow information between the models to be 
shared more frequently and seamlessly. Topographic and bathymetric data were collected by $\mathrm{UNC}-\mathrm{CH}$ IMS and RENCI and utilized in the development of the unstructured grid mesh (Fig. 3) for the tidal portions of the Tar-Pamlico and Neuse River basins.

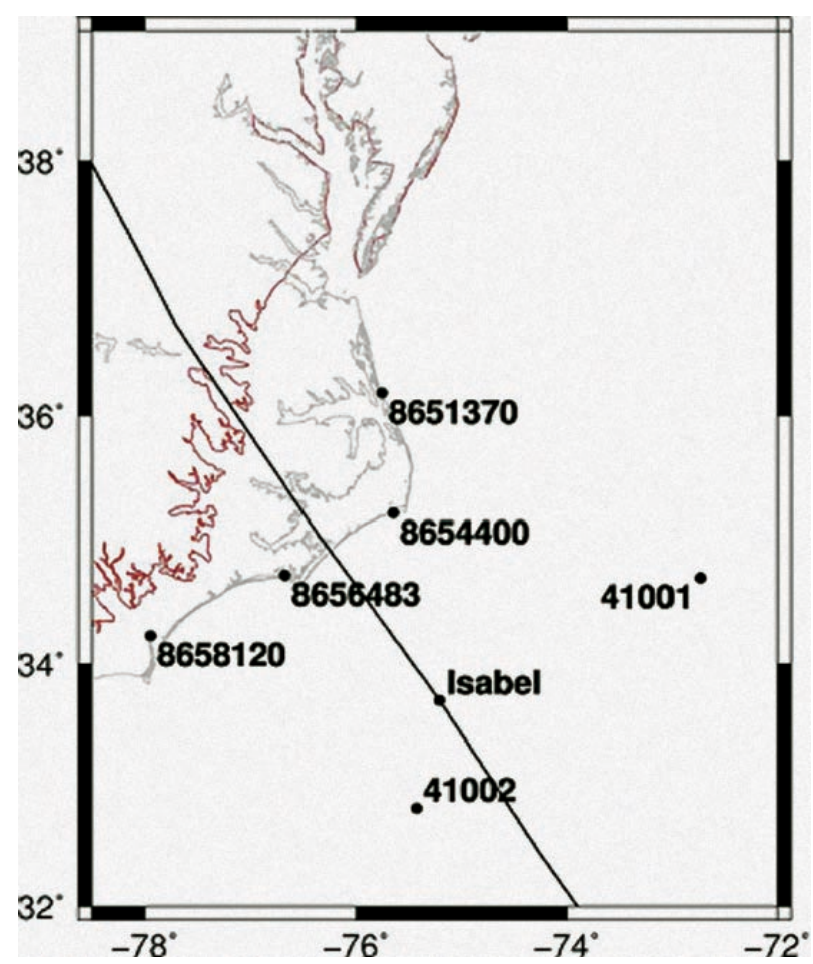

FIg. 4. Location of the two NDBC buoy stations for wave height validation of SWAN and the four NOS stations for total water level validation of ADCIRC+SWAN. The track of Hurricane Isabel is indicated by the solid black line.

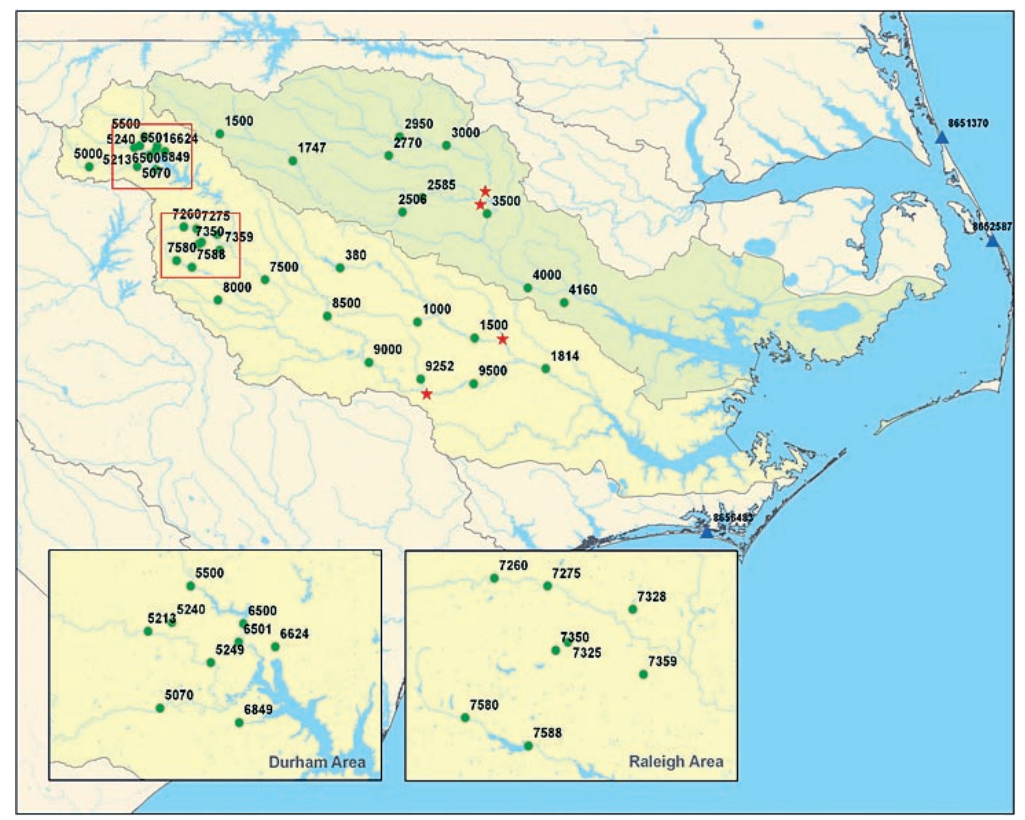

Model coupling. Over the course of the CI-FLOW project, questions have been raised regarding the best approach to couple the hydrologic model and hydrodynamic models, given the underlying model physics and subsequent limitations. One suggested approach was to insert a hydraulic river model between a hydrologic model and a hydrodynamic model. The hydraulic river model would then handle fluxes in the coastal plain generated by two-way tidal or storm surge flow and pass the fluxes as input into the hydrodynamic model. A second approach was to extend the hydrodynamic model well upstream of the historical storm surge zone on the Tar-Pamlico and Neuse Rivers and connect it directly to a hydrologic model. This latter approach eliminates the need for the intermediate hydraulic river model and relies on the hydrodynamic model to simulate the twodirectional flow in the rivers and tidal plain.

The CI-FLOW research team chose to extend the hydrodynamic model upstream of the historical storm surge zone, although there are trade-offs. With respect to locations within the ADCIRC+SWAN tidal plain domain, it is important to clarify that ADCIRC does not currently have the ability to account for the rainfallrunoff process. This fact has implications for extreme rainfall events occurring seaward of the handoff point between the models. However, research is under way to add capabilities to ADCIRC to account for overland runoff within the storm surge/tidal zone.

While historical storm surges on these rivers typically do not propagate past the 6-m land elevation contour, the upstream boundaries for the hydrodynamic model (i.e. ADCIRC+SWAN) were initially chosen to follow the $15-\mathrm{m}$ elevation contour. For CI-FLOW, it

FIG. 5. USGS locations and gauge numbers used for the Hurricane Isabel hindcast. Red stars indicate the location of the ADCIRC-HL-RDHM handoff points. In the Tar-Pamlico basin (shaded green), handoff point I on the Tar-Pamlico mainstem is upstream of USGS gauge 3500. Handoff point 2 on Fishing Creek is downstream of USGS gauge 3500 , above the confluence of Fishing Creek and the Tar-Pamlico. In the Neuse River basin (shaded yellow), handoff point I on the Neuse River mainstem is above USGS gauge 9500 . Handoff point 2 on Contentnea Creek is downstream of USGS gauge 1500 , above the confluence of Contentnea Creek and the Neuse River. 
is important that the backwater effects of storm surge will not enter the domain of the hydrologic model (i.e. HL-RDHM), which is not capable of simulating two-directional flow because of its kinematic wave channel routing algorithm. However, the number and size of grid elements required by ADCIRC+SWAN to accurately resolve the channel and floodplains of each of the rivers at the $15-\mathrm{m}$ land elevation would create severe computational constraints. Therefore, the grid for ADCIRC+SWAN was refined to approximately the 8-m contour for the mainstem of the Tar-Pamlico and the Neuse River and two significant tributaries, Fishing Creek and Contentnea Creek (Fig. 1).

Demonstration and performance assessment of hindcast system. Archived data from Hurricane Isabel (September 2003) were used to test the CI-FLOW hindcast coupled modeling system (Fig. 2). Hurricane Isabel was specifically chosen to leverage QPE data previously generated by NSSL as a partner in a multiyear research collaboration between NSSL, OHD, and the National Environmental Satellite, Data, and Information Service (Kitzmiller et al. 2009, 2010, 2011). For this collaboration, QPE fields were derived using the NSSL (Q2) and OHD (MPE) systems. NSSL generated QPE data using archived Weather Surveillance Radar-1988 Doppler level II data, rain gauge reports, and atmospheric environmental data information from archives of the RUC numerical model using the NSSL National Mosaic and Multi-Sensor QPE system (Zhang et al. 2009). OHD derived multisensor precipitation fields using the NWS MPE system (Habib et al. 2009; Fulton 2002). These QPE data fields were used as initial conditions for the HL-RDHM.

Hurricane Isabel made landfall as a category 2 storm on the Saffir-Simpson scale along the Outer Banks of North Carolina, between Cape Lookout and Ocracoke Island, at approximately 1600 UTC 18 September 2003 (Fig. 4). Hydrographs of discharge were produced on 15-min time steps by the HL-RDHM, which was forced with QPE from the NWS MPE system. Verification statistics (Nash and Sutcliffe 1970) were derived for all USGS gauge sites upriver of the four handoff points (Fig. 5) and selected sites just downstream of the handoff points but well upstream of the coastal plain. Verification results are shown in Figs. 6 and 7 for the Tar River at Tarboro (02083500), Fishing Creek near Enfield (02083000), Contentnea Creek at Hookerton (02091500), and the Neuse River near Goldsboro (02089000). These verification results show high Nash-Sutcliffe values, indicating good agreement between the HL-RDHM simulations and USGS gauge data in terms of water volume and time of peak.
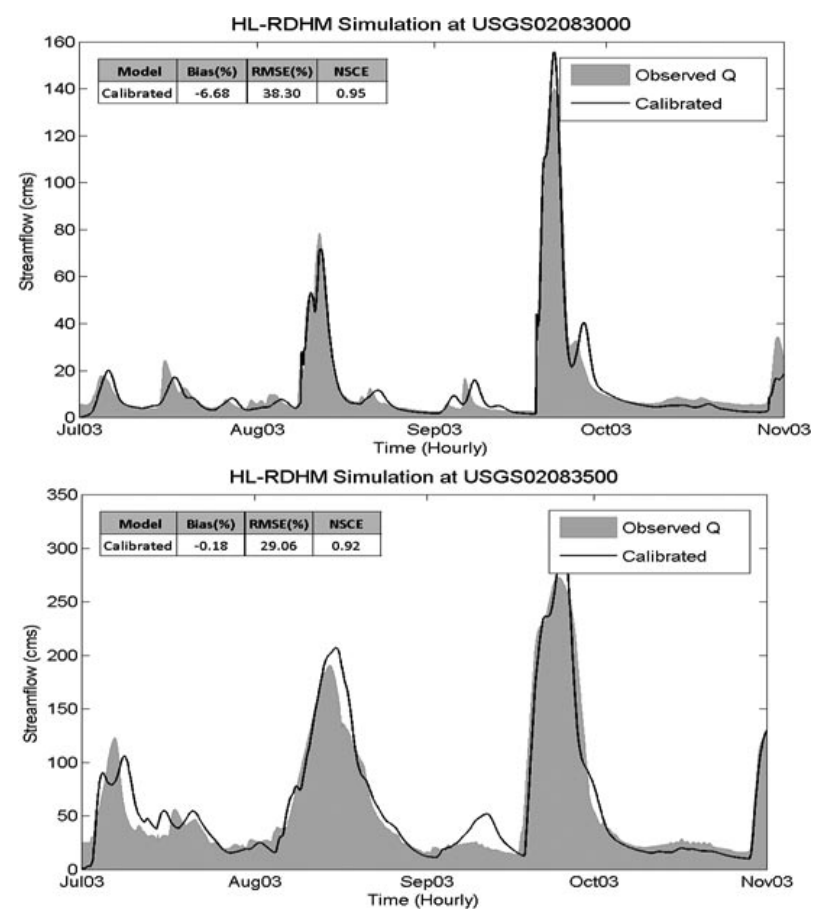

FIG. 6. Tar River basin hydrographs of optimized HL-RDHM simulation for USGS gauge 02083000 (3000), Fishing Creek near Enfield, NC, and USGS gauge 02083500 (3500), Tar River at Tarboro, NC, for Hurricane Isabel hindcast.
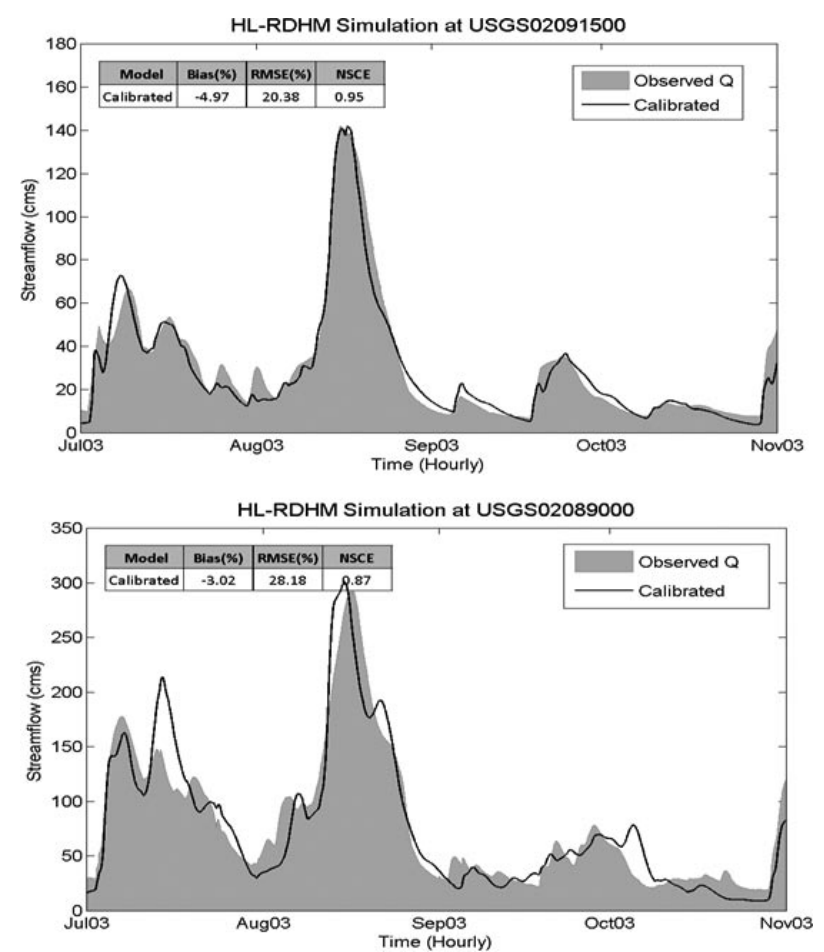

FIG. 7. Tar River basin hydrographs of optimized HLRDHM simulation for USGS gauge 02091500 (1500), Contentnea Creek at Hookerton, NC, and USGS gauge 02089000 (9000), Neuse River at Goldsboro, NC. 

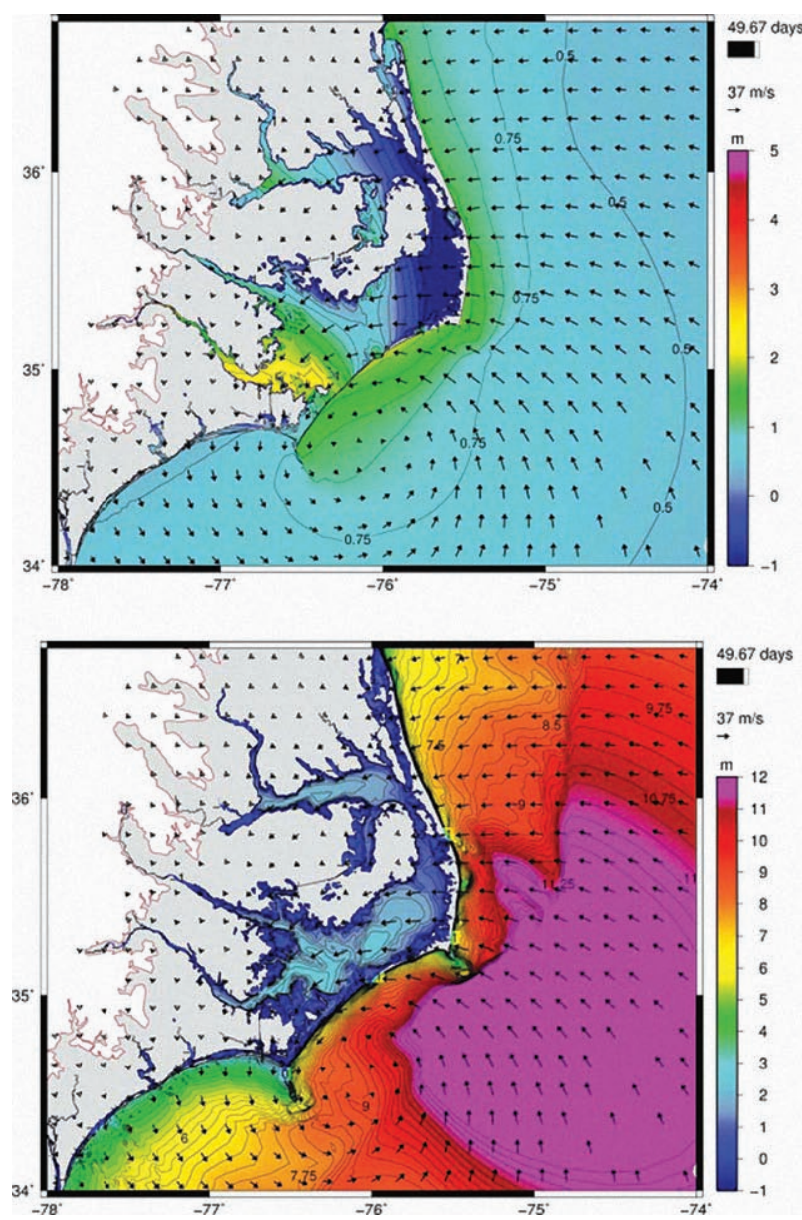

Fig. 8. Hurricane Isabel water levels and waves at 1600 UTC I 8 Sep 2003 for the coastal regions of North Carolina: (a) total water level $(\mathrm{m})$ and wind vectors $\left(\mathrm{m} \mathrm{s}^{-1}\right)$ and $(\mathrm{b})$ significant wave heights $(\mathrm{m})$ and wind vectors $\left(\mathrm{m} \mathrm{s}^{-1}\right)$.
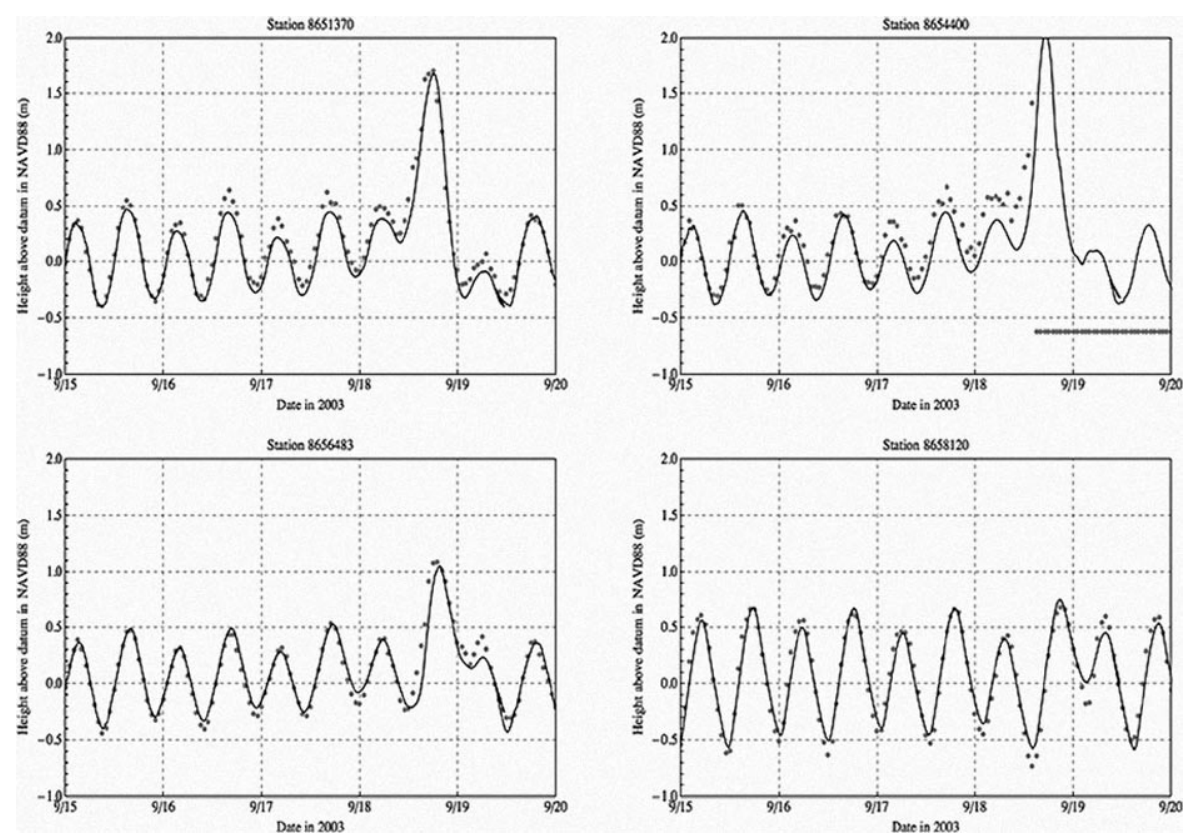

As shown in Fig. 2, data assimilation techniques provided optimized winds blended from the Interactive Objective Kinematic Analysis system (Cox et al. 1995; Cardone et al. 2007), the NOAA Hurricane Research Division's Wind Analysis System (Powell et al. 1998), and the NCEP-National Center for Atmospheric Research reanalysis project (Kalnay et al. 1996), along with the actual storm track, for use in ADCIRC+SWAN. Further details on the blending of wind products can be found in Bunya et al. (2010). For the Hurricane Isabel hindcast, ADCIRC+SWAN used freshwater flows from Tar River, Fishing Creek, Neuse River, and Contentnea Creek, obtained from HL-RDHM. Figure 8 illustrates the spatial distribution of the observed total water level and significant wave heights, along with the wind field, for Hurricane Isabel as the storm made landfall at 1600 UTC 18 September 2003 in North Carolina. Water began to inundate the land along the Outer Banks as Isabel made landfall (Fig. 8a). Furthermore, wave heights showed significant increases as the waves began to shoal in the shallower waters of the coastal shelf (Fig. 8b). In the Pamlico Sound, the significant wave heights are less than oceanward of the barrier islands because of the limited fetch length and shallow water depths within the sound.

Data from NOAA NDBC buoys and USGS river stations were used to validate simulations produced by the CI-FLOW hindcast system. The hindcast modeling system accurately captured the storm surge of Hurricane Isabel at the buoy stations (Fig. 9). The unstructured version of SWAN accurately simulated the wave heights during the peak of the storm; however, prestorm wave heights were underpredicted because of the initialization, or "spinup," phase of SWAN (Fig. 10). Finally, Fig. 11 illustrates the results from an upland station, Tar River at Greenville (02084000), dominated by freshwater runoff

FIG. 9. Comparison of the Hurricane Isabel simulation results for total water level $(\mathrm{m})$ obtained from ADCIRC+SWAN (solid black lines) to the NOAA NOS buoy stations (gray dots). 

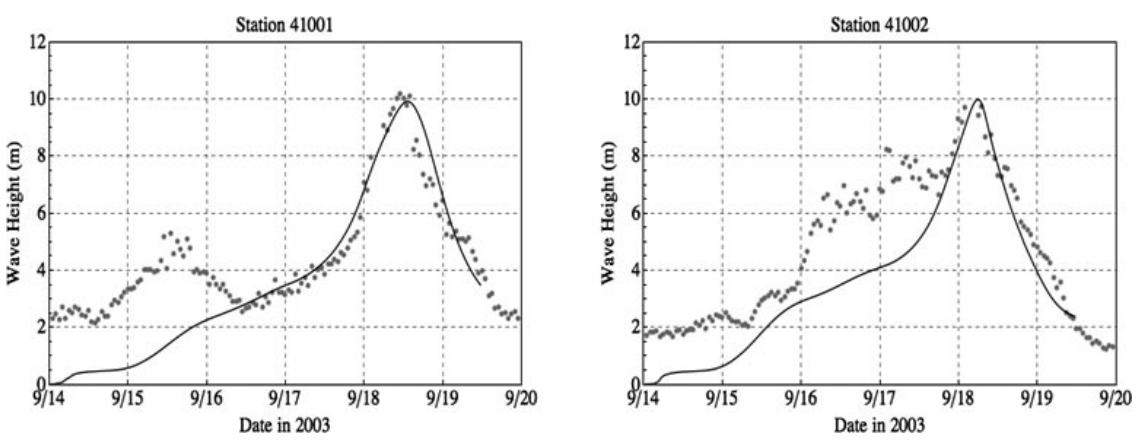

FIG. 10. Comparison of the significant wave heights $(m)$ from SWAN (solid black lines) for the Hurricane Isabel simulation to the NOAA NDBC buoy stations (gray dots).

instead of storm surge. The coupled system captured the rising limb of the hydrograph, but overpredicted water levels during the low-flow periods. Comparisons of ADCIRC+SWAN-generated rating curves to those obtained from the USGS indicated that the low-flow overshoot was primarily caused by poor resolution of the river bed for baseflow conditions. In that the intent of the system is to accurately simulate high-flow events, the discrepancies observed at low-flow conditions are not a concern.

\section{DEMONSTRATION OF THE CI-FLOW} REAL-TIME SYSTEM. Beginning with the 2010 Atlantic hurricane season, CI-FLOW successfully demonstrated the operation of a loosely coupled modeling system that exchanges information across multiple organizations and disparate computing infrastructures to produce water quantity simulations from the headwaters of the Tar-Pamlico and Neuse Rivers out to the Atlantic Ocean. The CI-FLOW realtime modeling system (Fig. 2) utilizes computing resources at NSSL, OU, and RENCI at UNC-CH (Ramakrishnan et al. 2006). The exchange of data between computing resources relies on the open-source freeware LDM (www.unidata.ucar.edu/software $/ \mathrm{ldm} /)$. The current automated system operates $24 \mathrm{~h}$ a day, 7 days a week with limited human interaction, thus reducing the possibility for human-induced errors. The structure of the system was also designed to accommodate multiple models and datastreams, which will facilitate ensemble forecasts as CI-FLOW pursues its long-term goal of an ensemble approach to total water level prediction.

Beginning with the 2010 hurricane season, the HL-RDHM routinely produces discharge forecasts on 15-min intervals for a 7-day period at NSSL 4 times a day (0000, 0600, 1200, 1800 UTC). NSSL Q2 QPE provides the forcing data for antecedent precipitation, and NOAA's HPC QPF provides estimates of future precipitation. Once routine simulations from the HL-RDHM were initiated, 4 times a day at RENCI, ADCIRC+SWAN produced 3-5-day total water level forecasts, depending on atmospheric forcing (NHC or NAM data).

The first real-time demonstration of the CI-FLOW system occurred during Hurricane Earl in September 2010. A second demonstration occurred with the remnants of Tropical Storm Nicole later in the month. ADCIRC+SWAN used the NHC's official storm-track forecast and an enhanced version of the Holland parametric hurricane model (Holland 1980; Mattocks and Forbes 2008) to simulate the storm's wind and pressure fields (Fig. 2) for Hurricane Earl. When the NHC's official storm track is not available, as was the case with Tropical Storm Nicole, ADCIRC+SWAN used NAM forecast guidance in place of NHC guidance.

For the Hurricane Earl and Tropical Storm Nicole events, the CI-FLOW real-time system produced a suite of hydrologic products, including the depiction of maximum total water level (river flows + tides + storm surge + waves) and inundation for the CDAs of the Tar-Pamlico and Neuse River basins. Figure 12 shows the simulation of maximum significant wave height and Fig. 13 shows maximum inundation (produced by subtracting surface elevation from total water level) generated by the real-time CI-FLOW system from the 2 September 2010 afternoon model run for Hurricane Earl. CI-FLOW simulated a maximum

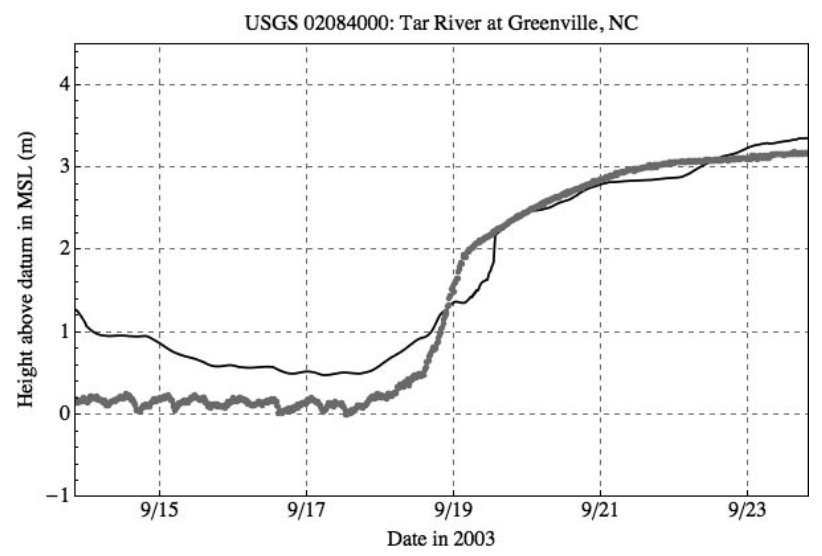

FIG. II. Comparison of total water level for ADCIRC and HL-RDHM (thin line) to USGS river gauging station (thick line) at Greenville, North Carolina. 


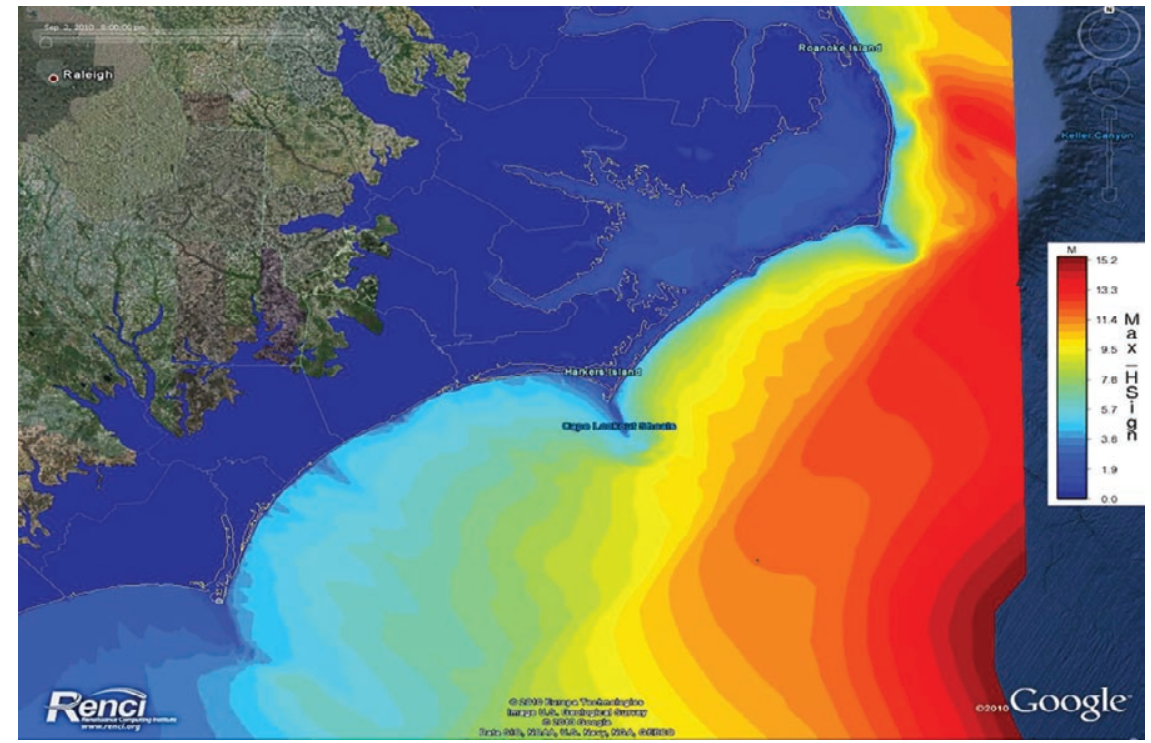

FIG. I2. ADCIRC+SWAN significant wave height $(\mathrm{m})$ simulation produced the afternoon of 2 Sep 2010 for Hurricane Earl.

significant wave height of $12-13 \mathrm{~m}(39-42 \mathrm{ft})$ for Hurricane Earl (Fig. 12). At 0850 UTC 3 September, NDBC buoy 41001 (Fig. 4) reported an $11.30 \mathrm{~m}$ $(37.07 \mathrm{ft})$ significant wave height. Figure 14 shows the simulation of maximum total water level from the 29 September 2010 afternoon model run for Tropical Storm Nicole.

Although only flows from the HL-RDHM were used for these storms, flexibility was built into the CI-FLOW system structure to bring discharge hydrographs from many sources, including USGS stations, river forecast center predictions, other hydrologic models, and synthetic hydrographs to serve as forcing for ADCIRC+SWAN. The modular design of the system will help facilitate future CI-FLOW enhancements, such as multimodel ensemble systems, leading toward quantification of uncertainty and probabilistic forecasts.

2010 hurricane season product delivery and stakeholder engagement. CI-FLOW is an interdisciplinary partnership that includes NOAA's
NSG Office; the NSG weather/climate extension specialist at OU; the Sea Grant Programs in North Carolina, South Carolina, and Texas; and OU's Social Science Woven into Meteorology. These groups work together to strengthen the efforts of transferring CIFLOW research outcomes and information to stakeholders in North Carolina.

The primary conduit for CI-FLOW research outcomes is the CI-FLOW web page (www.nssl.noaa gov/ciflow). From this web page, CI-FLOW researchers and collaborators, including NWS forecasters, can access a password-protected area to view water quantity (total water level from the coupled system and discharge from the hydrologic model) simulations for the two river basins and the Pamlico Sound. CI-FLOW is leveraging the NOAA's nowCOAST GIS web mapping portal and other NOAA hydrologic visualization platforms and formats to display this information.

Conveying the initial CI-FLOW research results to forecasters presents a challenging problem

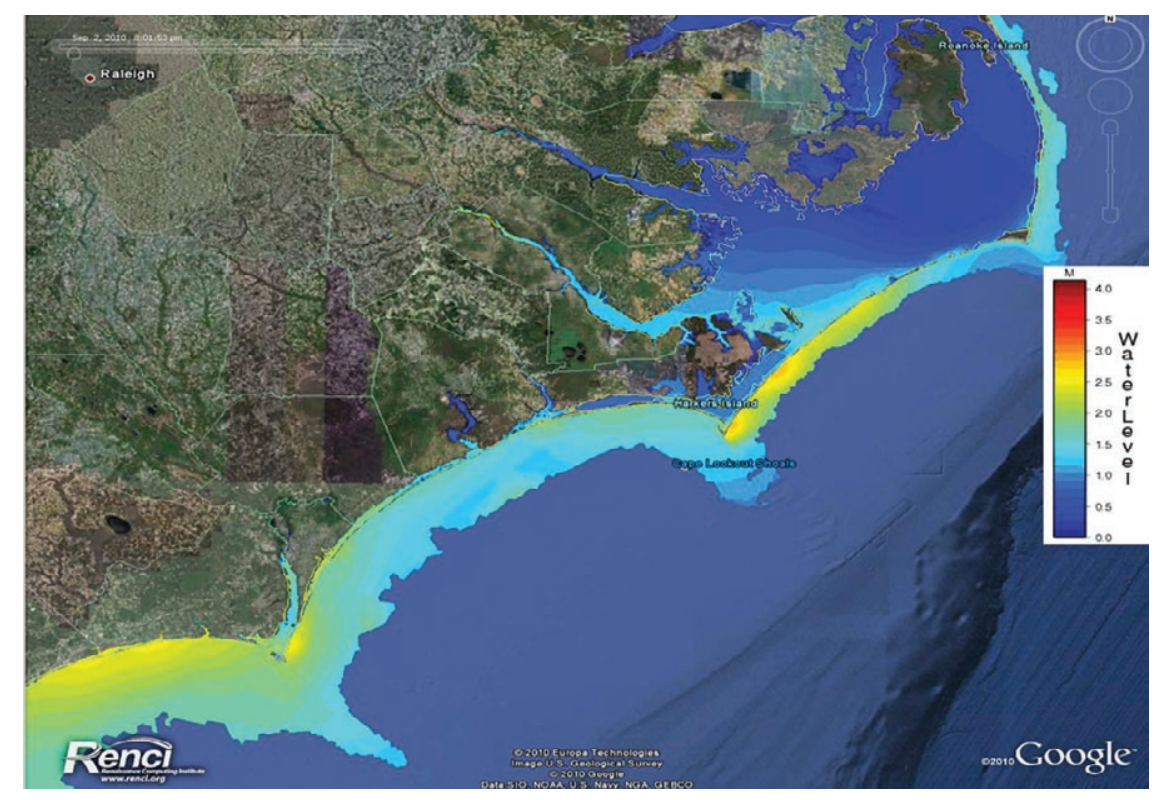

FIG. 13. Simulation of maximum inundation ( $m$ ) for Hurricane Earl produced by $\mathrm{CI}$-FLOW real-time system. Inundation calculated by subtracting surface elevations from total water level elevations, which account for freshwater flows from HL-RDHM and tides, waves, and surge from ADCIRC+SWAN. 
that is highly relevant to transitioning CI-FLOW outcomes to NOAA forecasting and warning services. Researchers and information users-in this case, primarily operational forecasters-are typically in different institutional settings, each with different sets of communication skills, attitudes, knowledge, social systems, and cultures. Thus, the role of outreach and education in the CI-FLOW scientific process is to help the "source" of information (researchers) reciprocally communicate with the "receiver" (information users) in an iterative process that ultimately results in satisfied users. The key is to understand

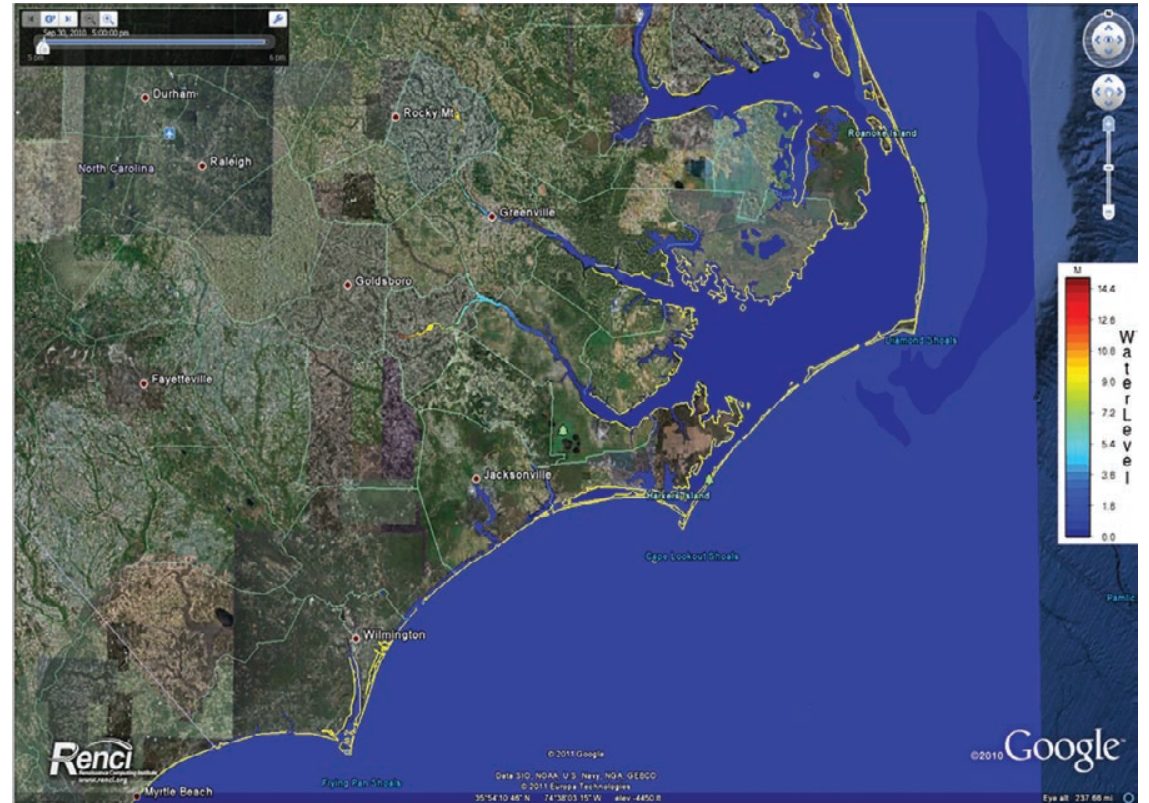

Fig. 14. Simulation of total water level elevation $(\mathrm{m})$ produced the afternoon of 29 Sep 2010 for Tropical Storm Nicole. Note the higher water levels in the ADCIRC+SWAN domain on the Neuse River system downstream of Goldsboro and on the Tar-Pamlico River system between Rocky Mount and Greenville. the context in which both

the source and the receiver operate, then to design ways that accurately transmit the information so that it can be easily understood and appreciated by the receiver. As demonstrated in the 2010 Atlantic hurricane season, CI-FLOW products will provide new water information to stakeholders who may require assistance interpreting the results. The form in which this information is presented to the public has consequences in how individuals perceive and react to the threat depicted by the forecast.

The interdisciplinary nature of the CI-FLOW research team provides the expertise to build and sustain a feedback loop to allow receivers the ability to modify and improve message format and delivery, thus enhancing productive communications between researchers and products users. In addition to leveraging existing NOAA visualization portals ( $w w w$ .nowcoast.noaa.gov/) and inundation maps (http:// water.weather.gov/ahps/inundation.php) produced in collaboration with NOAA and the state of North Carolina, CI-FLOW uses its web page to stimulate discussion on how information is displayed to establish a conduit between researchers and receivers to increase the relevancy of CI-FLOW research. One example is how CI-FLOW provides users with inundation scenarios to begin a dialogue on how to best convey forecast uncertainty with respect to the peak and timing of flood waters and, eventually, probabilistic forecasts produced by multiple model combinations. Ideally, this dialogue will initiate interactive discussions between forecasters and scientists on how best to explain the uncertainty inherent in hydrologic and hydrodynamic forecasts in light of NOAA's efforts to develop probabilistic forecasts.

\section{SUMMARY AND FUTURE DIRECTIONS.}

The CI-FLOW research team developed a prototype of a coupled modeling system that connects a hydrologic model forced with high-resolution QPE/QPF to a hydrodynamic model forced with river discharge, tidal elevations, and atmospheric and wave BCs. The CI-FLOW modeling system successfully produced simulations of total water level, accounting for tides, storm surge, waves, river flows, and rainfall, within North Carolina CDAs in real-time for Hurricane Earl and Tropical Storm Nicole (2010). Additional research assessments of the system and the accuracy of its simulations are underway and will be reported in the future. Although originally intended for landfalling hurricanes, the CI-FLOW system is capable of operating year-round and may be applied to all types of coastal storms, including intense coolseason extratropical cyclones (i.e., nor'easters). In addition, the CI-FLOW hindcast system can be used as a planning tool by coastal managers to simulate the effect of historical and/or hypothetical storms 
on a community, thus creating an opportunity to enhance resiliency through science-based community planning and emergency response.

The CI-FLOW project focused on two adjacent coastal basins, the Tar-Pamlico and Neuse, in North Carolina to build a unique research collaboration that addresses a critical NOAA service gap that affects coastal residents. Performance of components from the coupled modeling system from past storm events demonstrate that CI-FLOW produces realistic simulations of total water level. Most importantly, this system incorporates elements (i.e., HL-RDHM, ADCIRC, NOAA nowCOAST, and NSSL QPE) that are being considered for transition to NOAA operations within the next few years. These programs create a federal backbone of NOAA-supported programs that, for the most part, are available nationally and can be locally customized for implementation within coastal watershed research programs.

CI-FLOW partnerships with other academic and federal research programs are emerging and have the potential to add significant capabilities. Several ongoing research collaborations between NSSL, OHD, OU, and NASA are being leveraged to improve the accuracy and quantify the uncertainty of forecasts from the CI-FLOW system. At NSSL,

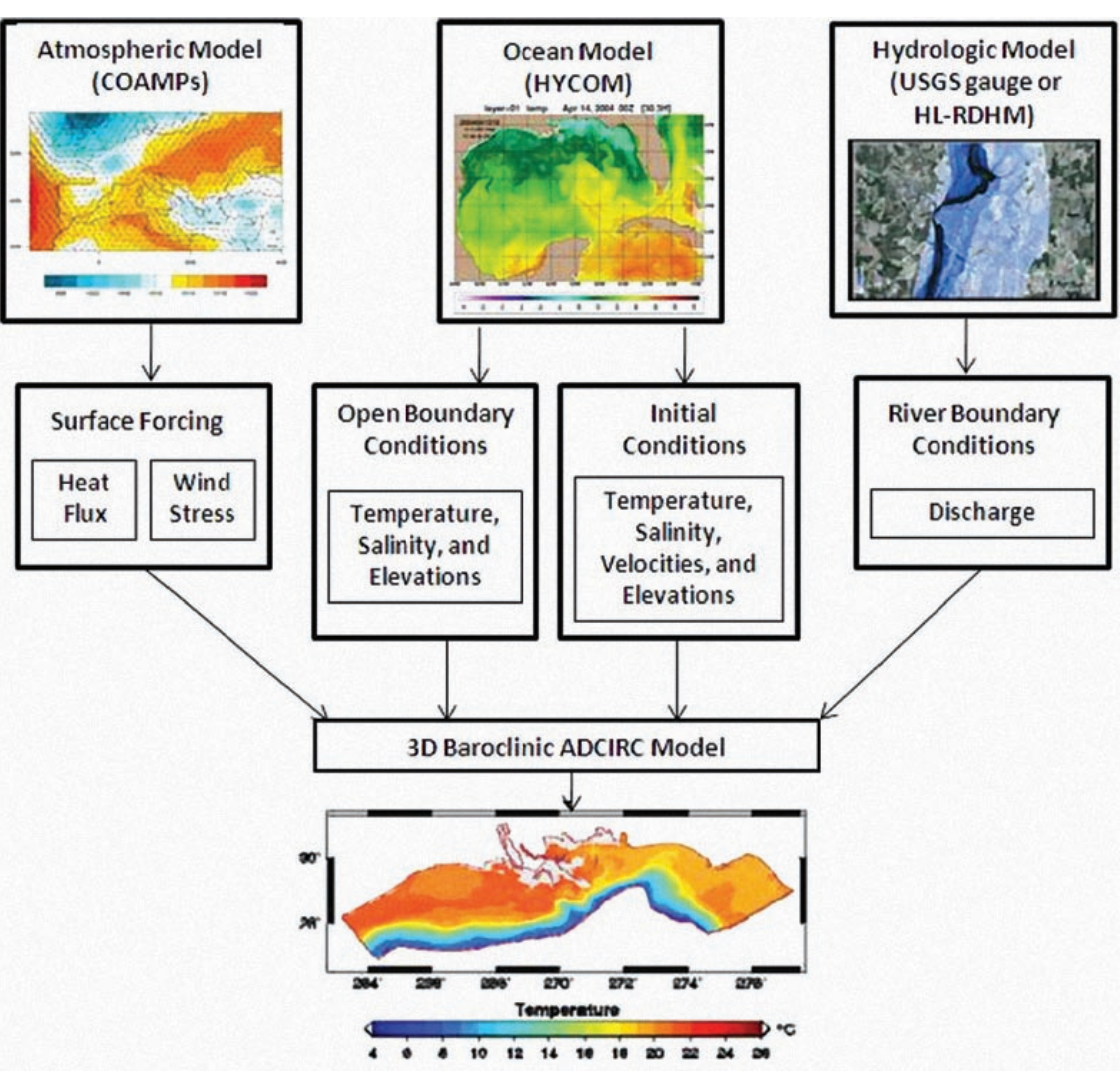

FIG. I5. Schematic of the coupled HYCOM-ADCIRC system. researchers are developing methods to assimilate satellite information on cloud tops and other atmospheric characteristics to improve precipitation estimates. Additional research efforts are focused on using dual-polarization radar fields and data from non-NWS radar networks to improve radarcentric precipitation estimates. Collaborations between NSSL, OU, and NASA have successfully implemented additional hydrologic models (i.e., CREST) in other river basins. These models are being targeted for implementation in the Tar-Pamlico and Neuse River basins to help build the capacity for ensemble forecasting.

Responding to needs assessments from project stakeholders, CI-FLOW researchers started working on expanding the capabilities of the real-time system to incorporate the ability to capture the intrusion of saline water into the estuaries of North Carolina. Research using three-dimensional ADCIRC has been completed to simulate the dynamic effect of saline waters at tidal interfaces (Kolar et al. 2009). To accomplish this, ADCIRC has been coupled to the structured global or regional ocean model HYCOM (Chassignet et al. 2003, 2006). Initial and boundary conditions for salinity and temperature are obtained from HYCOM and used in the three-dimensional ADCIRC. A schematic of the coupled system is shown in Fig. 15 (Blain et al. 2009; Dresback et al. 2010). Additionally, the CI-FLOW team is working with the Environmental Protection Agency to explore coupling ADCIRC with water quality models. These developments, along with collaborations with USGS (storm surge monitoring and high-watermark programs for validation), FEMA (flood mapping), NOAA's CSC, and Illinois/ Indiana Sea Grant (land use decision support tools) are in development to address critical needs expressed by residents focused on creating resilient coastal ecosystems.

The CI-FLOW project has the potential to be a valuable research tool for 
NOAA. CI-FLOW demonstrates a viable system that can be transitioned to other coastal watersheds. Most importantly, CI-FLOW directly supports NOAA's mission to ensure the ecological and economic wellbeing and productivity of ecosystems and the coastal communities that depend upon them. The CI-FLOW hindcast and real-time system demonstrates not only the capability for day-to-day total water level prediction but also provides the capability to build a library of past and future scenarios and decision support tools to aid in land use and community resiliency planning in the face of sea level rise.

ACKNOWLEDGMENTS. The CI-FLOW project would not have been possible without the pioneering discussions between NSSL and NOAA Sea Grant. Thanks to the members of the vision team: Ron Baird, director of NOAA Sea Grant (retired), and James Kimpel, director of NSSL (retired). Additional thanks go to our advocates and funding sponsors, including Andy Shepherd of NOAA's National Undersea Research Program, NOAA in the Carolinas, the NOAA Southeast and Caribbean Regional Team, and NOAA's CSC. Support for ADCIRC was provided, in part, through the Department of Homeland Security, Center of Excellence Contract 2008-ST-061ND0001-02, the NOAA IOOS Program through Contract NA07NOS4730212, the Cooperative Institute for Mesoscale Meteorological Studies' cooperative agreement funding by NOAA's Office of Oceanic and Atmospheric Research under NOAA-University of Oklahoma Cooperative Agreement NA17RJ1227 U.S. Department of Commerce, and NSSL, which the authors gratefully acknowledge. Any opinions, findings, conclusions, and recommendations expressed in this material are those of the authors and do not necessarily reflect those of the funding agencies. The authors also appreciate the comments and suggestions from three anonymous reviewers, which improved the structure of this manuscript.

APPENDIX: SUMMARY OF ACRONYMS.

$\begin{array}{ll}\text { ADCIRC } & \text { Advanced circulation } \\ \text { BC } & \text { Boundary condition } \\ \text { CAF } & \text { Coastal Assessment Framework } \\ \text { CDA } & \text { Coastal drainage area } \\ \text { CEES } & \text { Civil Engineering and Environmental Science } \\ \text { CI-FLOW } & \text { Coastal and Inland Flooding Observation and Warning } \\ \text { CREST } & \text { Coupled routing and excess storage } \\ \text { CSC } & \text { Coastal Services Center } \\ \text { FEMA } & \text { Federal Emergency Management Agency } \\ \text { HL-RDHM } & \text { Hydrology Lab Research Distributed Hydrologic Model } \\ \text { HPC } & \text { Hydrometeorological Prediction Center } \\ \text { HRAP } & \text { Hydrologic Rainfall Analysis Project } \\ \text { HUC } & \text { Hydrologic unit code } \\ \text { HYCOM } & \text { Hybrid Coordinate Ocean Model } \\ \text { IMS } & \text { Institute of Marine Sciences } \\ \text { IOOS } & \text { Integrated Ocean Observing System } \\ \text { LDM } & \text { Local Data Manager } \\ \text { MPE } & \text { Multisensor precipitation estimator } \\ \text { NAM } & \text { North American Mesoscale Model } \\ \text { NCEP } & \text { National Centers for Environmental Prediction } \\ \text { NDBC } & \text { National Data Buoy Center } \\ \text { NHC } & \text { National Hurricane Center } \\ \text { NOAA } & \text { National Oceanic and Atmospheric Administration } \\ \text { NSSL } & \text { National Severe Storms Laboratory } \\ \text { NOS } & \text { National Ocean Service } \\ \text { NSG } & \text { National Sea Grant } \\ \text { NWS } & \text { National Weather Service } \\ \text { OAR } & \text { Office of Oceanic and Atmospheric Research } \\ \text { OU } & \text { University of Oklahoma } \\ \text { OHD } & \text { Office of Hydrologic Development } \\ \text { PBL } & \text { Planetary boundary layer } \\ \text { Q2 } & \text { Quantitative Precipitation Estimation algorithm (second generation, multisensor) } \\ & \end{array}$




$\begin{array}{ll}\text { QPE } & \text { Quantitative precipitation estimate } \\ \text { QPF } & \text { Quantitative precipitation forecast } \\ \text { RENCI } & \text { Renaissance Computing Institute } \\ \text { RFC } & \text { River forecast center } \\ \text { RUC } & \text { Rapid Update Cycle } \\ \text { SERFC } & \text { Southeast River Forecast Center } \\ \text { STATSGO } & \text { State Soil Geographic } \\ \text { SWAN } & \text { Simulating Waves Nearshore } \\ \text { UNC-CH } & \text { University of North Carolina at Chapel Hill } \\ \text { USGS } & \text { U.S. Geological Survey }\end{array}$

\section{REFERENCES}

Benjamin, S. G., and Coauthors, 2004: An hourly assimilation/forecast cycle: The RUC. Mon. Wea. Rev., 132, 495-518.

Bin, O., and J. B. Kruse, 2006: Real estate market response to coastal flood hazards. Nat. Hazards Rev., 7, 137-144.

Blain, C. A., M. K. Cambazoglu, and V. H. Kourafalou, 2009: Modeling the Dardanelles strait outflow plume using a coupled model system. Proc. OCEANS 2009, Biloxi, MS, Marine Technical Society and Institute of Electrical and Electronics Engineers, 1-8. [Available online at http://ieeexplore.ieee.org/stamp/stamp.jsp? $\mathrm{tp}=$ \&arnumber $=5422421$ \&isnumber $=542205$.]

Booij, N., R. C. Ris, and L. H. Holthuijsen, 1999: A third-generation wave model for coastal regions 1 . Model description and validation. J. Geophys. Res., 104 (C4), 7649-7666.

— I. J. G. Haagsma, L. H. Holthuijsen, A. T. M. M. Kieftenburg, R. C. Ris, A. J. van der Westhuysen, and M. Zijlema, 2004: SWAN Cycle III, version 40.41. User manual, Delft University of Technology, 118 pp.

Bunya, S., and Coauthors, 2010: A high-resolution coupled riverine flow, tide, wind, wind wave, and storm surge model for southern Louisiana and Mississippi. Part I: Model development and validation. Mon. Wea. Rev., 138, 345-377.

Burnash, R. J. C., 1995: The NWS River Forecast System-Catchment modeling. Computer Models of Watershed Hydrology, V. P. Singh, Ed., Water Resources Publications, 311-366.

Cardone, V. J., and A. T. Cox, 2007: Tropical cyclone wind field forcing for surge models: Critical issues and sensitivities. Nat. Hazards, 51, 29-47.

Chassignet, E. P., L. T. Smith, G. R. Halliwell, and R. Bleck, 2003: North Atlantic simulations with the Hybrid Coordinate Ocean Model (HYCOM): Impact of the vertical coordinate choice, reference pressure, and thermobaricity. J. Phys. Oceanogr., 33, 2504-2526.

—, H. E. Hurlburt, O. M. Smedstad, G. R. Halliwell, P. J. Hogan, A. J. Wallcraft, and R. Bleck, 2006: Ocean prediction with the Hybrid Coordinate Ocean Model (HYCOM). Ocean Weather Forecasting: An Integrated View of Oceanography, E. P. Chassignet and J. Verron, Eds., Springer, 413-426.

Cox, A. T., J. A. Greenwood, V. J. Cardone, and V. R. Swail, 1995: An interactive objective kinematic analysis system. Proc. Fourth Int. Workshop on Wave Hindcasting and Forecasting, Banff, AB, Canada, Atmospheric Environment Service, 109-118.

Dietrich, J. C., and Coauthors, 2010a: A high-resolution coupled riverine flow, tide, wind, wind wave, and storm surge model for southern Louisiana and Mississippi. Part II: Synoptic description and analyses of Hurricanes Katrina and Rita. Mon. Wea. Rev., 138, 378-404.

— and storm surge using integrally-coupled, scalable computations. J. Coast. Eng., 58, 45-66.

Dow, K., and S. L. Cutter, 2002: Emerging hurricane evacuation issues: Hurricane Floyd and South Carolina. Nat. Hazards Rev., 3, 12-18.

Dresback, K. M., R. L. Kolar, C. A. Blain, C. M. Szpilka, A. M. Szpilka, R. A. Luettich, and T. Shay, 2010: Development and application of the coupled HYCOM and ADCIRC system. Estuarine and Coastal Modeling: Proceedings of the Eleventh International Conference, M. L. Spaulding, Ed., American Society of Civil Engineers, 259-277.

Forstall, R. L., 1995: Population of Counties by Decennial Census: 1900 to 1990. U.S. Census Bureau. [Available online at www.census.gov/population /cencounts/nc190090.txt.]

Fread, D. L., and Coauthors, 1995: Modernization in the National Weather Service River and Flood Program. Wea. Forecasting, 10, 477-484.

Fulton, R. A., 2002: Activities to improve WSR-88D radar rainfall estimation in the National Weather Service. Proc. Second Federal Interagency Hydrologic Modeling Conf., Las Vegas, NV, Interagency Advisory Committee on Water Data. [Available online at www .nws.noaa.gov/oh/hrl/presentations/fihm02/pdfs /qpe_hydromodelconf_web.pdf]. 
—, J. P. Breidenbach, D.-J. Seo, D. A. Miller, and T. O'Bannon, 1998: The WSR-88D rainfall algorithm. Wea. Forecasting, 13, 377-395.

Funakoshi, Y., S. C. Hagen, and P. Bacopoulos, 2008: Coupling of hydrodynamic and wave models: Case study for Hurricane Floyd (1999) hindcast. J. Waterw. Port Coastal Ocean Eng., 134, 321-335.

Glaudemans, M. J., R. A. Erb, E. B. Wells, J. Zimmerman, J. J. Hill-Maxwell, and K. S. Mack, 2002: Overview and status of the hydrologic forecast system in the National Weather Service Weather Forecast Offices. Preprints, Interactive Symp. on AWIPS, Orlando, FL, Amer. Meteor. Soc., J7.6. [Available online at http:// ams.confex.com/ams/annual2002/techprogram/ paper_28001.htm.]

Greene, D. R., and M. D. Hudlow, 1983: Hydrometeorological grid mapping procedures. Proceedings of the International Symposium on Hydrometeorology, A. I. Johnson and R. A. Clark, Eds., Technical Publication Series 82-1, American Water Resources Association.

Gunther, H., 2005: WAM cycle 4.5 version 2.0. Institute for Coastal Research, GKSS Research Centre, 38 pp.

Habib, E., B. F. Larson, and J. Graschel, 2009: Validation of NEXRAD multisensor precipitation estimates using an experimental dense rain gauge network in south Louisiana. J. Hydrol., 373, 463-478.

Hernandez, M., S. C. Miller, D. C. Goodrich, B. F. Goff, W. G. Kepner, C. M. Edmonds, and K. B. Jones, 2000: Modeling runoff response to land cover and rainfall spatial variability in semi-arid watersheds. Environ. Monit. Assess., 64, 285-298.

Holland, G. J., 1980: An analytic model of the wind and pressure profiles in hurricanes. Mon. Wea. Rev., 108, 1212-1218.

Kalnay, E., and Coauthors, 1996: The NCEP/NCAR 40-Year Reanalysis Project. Bull. Amer. Meteor. Soc., 77, 437-471.

Kildow, J. T., C. S. Colgan, and J. Scorse, 2009: State of the U.S. ocean and coastal economies. National Ocean Economics Program, 56 pp.

Kitzmiller, D. H., and Coauthors, 2009: A comparison of evolving multisensor precipitation estimation methods. Preprints, 23rd Conf. on Hydrology, Phoenix, AZ, Amer. Meteor. Soc., 6B.1. [Available online at http://ams.confex.com/ams/89annual /techprogram/paper_147255.htm.]

— evolving multisensor precipitation estimation methods based on impacts on flow prediction using a distributed hydrologic model. [Available online at http://ams.confex.com/ams/88Annual/techprogram /paper_134451.htm.]
— cipitation estimation methods: Their impacts on flow prediction using a distributed hydrologic model. $J$. Hydrometeor., in press.

Kolar, R. L., T. C. G. Kibbey, C. M. Szpilka, K. M. Dresback, E. M. Tromble, I. P. Toohey, J. L. Hoggan, and J. H. Atkinson, 2009: Process-oriented tests for validation of baroclinic shallow water models: The lock-exchange problem. Ocean Modell., 28, 137-152.

Koren, V., S. Reed, M. Smith, Z. Zhang, and D. J. Seo, 2004: Hydrology Laboratory Research Modeling System (HL-RMS) of the U.S. National Weather Service. J. Hydrol., 291, 297-318.

Larson, L. W., and Coauthors, 1995: Operational responsibilities of the National Weather Service River Flood Program. Wea. Forecasting, 10, 465-476.

Lin, Y., and K. E. Mitchell, 2005: The NCEP stage II/ IV hourly precipitation analyses: Development and applications. Preprints, 19th Conf. on Hydrology, San Diego, CA, Amer. Meteor. Soc., 1.2. [Available online at http://ams.confex.com/ams/Annual2005 /techprogram/paper_83847.htm.]

Luettich, R. A., Jr., J. J. Westerink, and N. W. Scheffner, 1992: ADCIRC: An Advanced Three-Dimensional Circulation Model for Shelves, Coasts and Estuaries; Report 1: Theory and methodology of ADCIRC2DDI and ADCIRC-3DL. DRP Technical Rep. DRP92-6. Department of the Army, U.S. Army Corps of Engineers, Waterways Experiment Station, 143 pp.

Mattocks, C., and C. Forbes, 2008: A real-time, eventtriggered storm surge forecasting system for the state of North Carolina. Ocean Modell., 25, 95-119.

McEnery, J., J. Ingram, Q. Duan, T. Adams, and L. Anderson, 2005: NOAA's Advanced Hydrologic Prediction Service. Bull. Amer. Meteor. Soc., 86, 375-885.

McKee Smith, J., A. R. Sherlock, and D. T. Resio, 2001: STWAVE: Steady-State Spectral Wave Model user's manual for STWAVE, version 3.0. U.S. Army Corps of Engineers Rep. ERDC/CHL SR-01-1, 81 pp.

Miller, D. A., and R. A. White, 1998: A conterminous United States multilayer soil characteristics dataset for regional climate and hydrology modeling. Earth Interactions, 2. [Available online at http:// EarthInteractions.org.]

Moreda, F., V. Koren, Z. Zhang, S. Reed, and M. Smith, 2006: Parameterization of distributed hydrological models: Learning from the experiences of lumped modeling. J. Hydrol., 320, 218-237.

Nash, J. E., and J. V. Sutcliffe, 1970: River flow forecasting through conceptual models. Part I-A discussion of principles. J. Hydrol., 10, 282-290. 
NOAA, cited 2010: NOAA's coastal geospatial data project. [Available online at http://coastalgeospatial .noaa.gov/.].

North Carolina Office of State Budget and Management, cited 2011: County estimates. [Available online at www.osbm.state.nc.us/ncosbm/facts_and_ figures/socioeconomic_data/population_estimates /county_estimates.shtm.]

Pietrafesa, L., and Coauthors, 2006: A new architecture for coastal inundation and flood warning protection. Mar. Technol. Soc. J., 40, 71-77.

Powell, M. D., S. H. Houston, L. R. Amat, and N. Morrisseau-Leroy, 1998: The HRD real-time hurricane wind analysis system. J. Wind Eng. Ind. Aerodyn., 77\&78, 53-64.

Ramakrishnan, L., B. O. Blanton, H. M. Lander, R. A. Luettich Jr., D. A. Reed, and S. R. Thorpe, 2006: Realtime storm surge ensemble modeling in a grid environment. Proc. Second Int. Workshop on Grid Computing Environments (GCE'06), Tampa, FL, Institute of Electrical and Electronics Engineers and Association for Computing Machinery (ACM), Paper 111. [Available online at www.renci.org/wp-content/pub/scoop /presentations/SCOOPPaper-GCEFinal.pdf.]

Reed, S. M., and D. R. Maidment, 1999: Coordinate transformations for using NEXRAD data in GISbased hydrologic modeling. J. Hydrol. Eng., 4, 174-182.

_- and Coauthors, 2004: Overall distributed model intercomparison project results. J. Hydrol., 298, 27-60.

Ris, R. C., L. H. Holthuijsen, and N. Booij, 1999: A third-generation wave model for coastal regions. 2. Verification. J. Geophys. Res., 104 (C4), 7667-7681.

Smith, M. B., D. P. Laurine, V. I. Koren, S. Reed, and Z. Zhang, 2003: Hydrologic model calibration in the National Weather Service. Calibration of Watershed Models, Q. Duan et al., Eds., Water Science and Application Series, Vol. 6, Amer. Geophys. Union, 133-152.

—, D.-J. Seo, V. I. Koren, S. M. Reed, Z. Zhang, Q. Duan, F. Moreda, and S. Cong, 2004: The Distributed Model Intercomparison Project (DMIP): Motivation and experiment design. J. Hydrol., 298, 4-26.

Soil Survey Staff, 1994: State Soil Geographic Database (STATSGO) data users guide. USDA Natural Resources Conservation Service Misc. Publ. 1492, U.S. Government Printing Office, 88-1036.

_ 1996: Soil survey laboratory methods manual. Soil Survey Investigations Rep. 42, version 2.0, National Soil Survey Center, Soil Conservation Service, U.S. Department of Agriculture, 693-1036.

Stallings, E. A., and L. A. Wenzel, 1995: Organization of the river and flood program in the National Weather Service. Wea. Forecasting, 10, 457-464.
Tolman, H. L., 2009: User manual and system documentation of WAVEWATCH III version 3.14. MMAB Tech. Note 276, $194 \mathrm{pp}$.

Urbina, E., and B. Wolshon, 2003: National review of hurricane evacuation plans and policies: A comparison and contrast of state practices. Transp. Res., 37A, 257-275.

U.S. Census Bureau, 2001: Profiles of General Demographic Characteristics-2000 Census of Population and Housing North Carolina. [Available online www .census.gov/prod/cen2000/dp1/2kh37.pdf.]

—, 2004: Annual Estimates of the Population for Counties: April 1, 2000 to July 1, 2004. [Available online at www.census.gov/popest/counties /CO-EST2004-01.html.]

USDA Natural Resources Conservation Service, 1994: State Soil Geographic (STATSGO) Database. Soil Conservation Service Miscellaneous Publ. 1492, 37 pp.

Vasiloff, S. V., and B. Kaney, 2007: The National Severe Storms Laboratory's QPE verification system. Extended Abstracts, 24th Conf. on IIPS, New Orleans, LA, Amer. Meteor. Soc., 6B.12. [Available online at http://ams.confex.com/ams/88Annual/techprogram /paper_133921.htm.]

_- and Coauthors, 2007: Improving QPE and very short term QPF: An initiative for a community-wide integrated approach. Bull. Amer. Meteor. Soc., 88, 1899-1911.

WAMDI Group, 1988: The WAM model-A third generation ocean wave prediction model. J. Phys. Oceanogr., 18, 1775-1810.

Westerink, J. J., C. A. Blain, R. A. Luettich Jr., and N. W. Scheffner, 1994: ADCIRC: An Advanced ThreeDimensional Circulation Model for Shelves, Coasts, and Estuaries; Report 2: User's manual for ADCIRC2DDI. DRP Tech. Rep. DRP-92-6, Department of the Army, U.S. Army Corps of Engineers, Waterways Experiment Station, $156 \mathrm{pp}$.

Willigen, M. V., B. Edwards, S. Lormand, and K. Wilson, 2005: Comparative assessment of impacts and recovery from Hurricane Floyd among student and community households. Nat. Hazards Rev., 6, 180-190.

Zhang, J., and Coauthors, 2009: National Mosaic and Q2 (NMQ) system-Description, results and future plans. Preprints, 34th Conf. on Radar Meteorology, Williamsburg, VA, Amer. Meteor. Soc., 7A.1. [Available online at http://ams.confex.com/ams/34Radar /techprogram/paper_155375.htm.]

— and _ 2011: National Mosaic and Multi-Sensor QPE (NMQ) system: Description, results, and future plans. Bull. Amer. Meteor. Soc., 92, 1321-1338.

Zijlema, M., 2010: Computation of wind-wave spectra in coastal waters with SWAN on unstructured grids. J. Coastal Eng., 57, 267-277. 